\title{
Potential for social learning in sustainable regional development: analysis of stakeholder interaction with a focus on the role of scientists
}

\author{
Jana Dlouhá, Martin Zahradník \\ Envigogika 10 (1) - Reviewed Papers/ Recenzované články
}

Published/ Publikováno 20. 6. 2015

DOI: $\underline{10.14712 / 18023061.476}$

\begin{abstract}
This article is concerned with regional development and its dimension of (un)sustainability: it analyses conditions for the success or failure of environmental or sustainable development strategies from a social point of view. The authors share their experience acquired within the process of compiling a database of case studies from different regions of the Czech Republic and from abroad, and subsequently provide a brief analytical overview of cases in this special issue. The analytical perspective focuses on the roles of actors in a dialogue about regional sustainability issues within cooperative or conflict situations, and a description of the communication processes at play, especially within the science - policy interface. An analytical tool (actor analysis) is employed to explore network characteristics, the relationships of the actors involved and the process of deliberation itself where different approaches to "nature", "environment", and/or "sustainable development" were conceived but often not agreed upon. Information and evidence included in the case studies from CR and abroad was coded according to the set of variables defined by actor analysis. Consequent comparative meta-analysis of these variables in different cases helped to formulate several hypotheses: for successful sustainable development at regional level, future visions should be discussed and shared by all stakeholders, including local citizens who seek to protect their well-being. Cases in which local actors had to choose between two polarised, controversial solutions, the usual outcome was a deadlock in communication. The establishment of a communication framework for actor involvement appeared to be beneficial. This finding provides an opportunity for scientists and experts to facilitate these processes in practice. The article shows how important it is to investigate the social aspects of development issues and map relationships between key and other actors to understand negotiation processes in order to influence democratic decision making at regional level.
\end{abstract}

\section{Key words}

Social learning; sustainable development; regional issues; actor analysis 


\begin{abstract}
Abstrakt
Článek se zabývá regionálním (ne)udržitelným rozvojem: analyzuje předpoklady pro to, aby strategie udržitelného rozvoje byly úspěšné nebo se naopak ukázaly předpoklady jejich selhání, a to ze sociálního úhlu pohledu. Autoři popisují a následně analyzují prípady tohoto typu z České republiky a ze světa, jež byly shromážděny pro databázi prŕpadových studií $\mathrm{i} v$ rámci tohoto čísla Envigogiky. Analytický zájem se soustřed’uje na role aktérů $\checkmark$ dialogu o regionálních problémech udržitelného rozvoje, jak se projevují v rámci jejich spolupráce nebo $v$ konfliktních situacích, a zabývá se souvisejícími procesy komunikace, zvláště na rozhraní mezi vědou a politikou. Analytický nástroj - metoda analýza aktérů byl využit pro zjištóvání charakteristik vztahů mezi zapojenými aktéry a jejich sítí; zájem se soustředil na povahu samotného procesu vyjednávání, v rámci kterého se střetávají různé, často kontroverzní, pohledy na "přírodu", "životní prostředí" nebo "udržitelný rozvoj", takže dosažení dohody v praxi je pak obtížné. Metodický postup vycházel z kódování informací obsažených $v$ případových studiích podle souboru proměnných, které byly definovány dle analytického zájmu samotné metody analýzy aktérů. Následná srovnávací meta-analýza těchto proměnných určených $v$ několika případech pomohla formulovat několik hypotéz: pro úspěšný udržitelný rozvoj na regionální úrovni je potřeba mít, diskutovat a sdílet vize budoucnosti, a to se všemi zainteresovanými aktéry včetně místních obyvatel, kteří se zajímají především o dobré životní podmínky (blahobyt). V případech, kde místní aktéři pouze vybírají ze dvou protichůdných možností, je ve výsledku vyjednávání obvykle zablokováno. Vytvoření rámce pro vyjednávání, do něhož by byli zapojeni všichni zainteresovaní aktéři, napomáhá mj. samotným procesům vyjednávání. Článek tak ukazuje, proč je důležité věnovat pozornost sociálním aspektům rozvojových problémů a co může přinést mapování vztahů mezi jejich klíčovými a dalšími aktéry - takový postup vede $k$ porozumění procesům deliberace a $v$ praxi pak podporuje demokratické postupy rozhodování na regionální úrovni.
\end{abstract}

\title{
Klíčová slova
}

Sociální učení; udržitelný rozvoj; regionální problémy; analýza aktérů 


\section{Introduction}

Sustainable development is a normative concept, based on empirical evidence of environmental degradation and creates strategies at different levels (from local to global) to avoid possible future risks. To implement these strategies in practice, broad discussions with societal actors including experts from diverse specializations are needed. Within the sustainability context, scientists are often required to provide their expertise in regard to highly complex environmental, social and/or economic issues that usually require transdisciplinary cooperation with other scientists, as well as with other social actors. The urgent need for policy-relevant results changes the notion of validity and the reliability of scientific knowledge (cf. Funtowicz, Ravetz, 2002), and open communication processes which accompany scientific engagement within a sustainability framework change the traditional roles of scientists (Hessels, Van Lente, 2008). The aim of this article is to explore these new roles of scientists in complex and ambiguous sustainability processes at a regional level and to identify "success factors" - the conditions under which science supports regional sustainable development solutions. To map this field, exploratory research in the Czech context focused on the investigation of communication processes (which open up possibilities for social learning) was undertaken. The research also sought to answer practical questions - it aimed to provide know-how and tools for the facilitation of the negotiation processes in the sustainability field, and especially to identify opportunities for scientific involvement.

\section{The environmental aspect of development}

The environmental (or ecological) point of view was historically developed based on evidence in the environmental sciences that first observed degradation in the environment and predicted a global environmental crisis. Commitment to prevent this was confirmed by the international community in numerous documents: for example, the 1972 UN Conference on the Human Environment in Stockholm stressed environmental management and assessment, the Club of Rome reported on the state of the natural environment, and the IUCN World Conservation Strategy launched internationally in 1980 introduced the actual term "sustainable development". This concept received prominence in 1987 as a core principle of societal transition (introduced by the report WCED Our Common Future). The concept itself has many interpretations, but its significance consists in a complex and future oriented perception of reality concerned with practical impact (Mebratu, 1998).

The Czech Republic, which is the focus of attention here, also has a relatively long tradition in environmental activities and related thinking, reflected in the educational system, including higher education (HE). Many environmental disciplines have flourished since the 1970s (cf. Dlouhá, Dlouhý, 2014) and many specialists with an environmental background have been working in different spheres of society. For example, the participation of scientists in environmental issues has thrived within the Ecological Section of the Biological Society of the Czechoslovak Academy of Sciences where there has been dialogue between different experts on pressing environmental problems (often in opposition to the communist regime in power at that time). Members of this Society have consequently contributed significantly to the social transformation that took place after 1990 and have often occupied influential positions within government. With their involvement, changes to legislation as well as environmental policies were passed shortly after 1989 - these mostly topdown strategies triggered enormous progress in the environmental field during the 1990s (cf. Vavroušek, Moldan, 1989; Vaněk, 1996). Another step in this development occurred as part of the EU accession process which was completed in 2004 (Kružíková, 2005). Since then, environmental policies have become relatively well established in relevant government institutions and strategies at the national, and to a less extent the regional level as 
well. But a well-planned decision making process that includes negotiation of planned solutions is still often lacking - in practice there are numerous conflicts between different social groups that occur in controversial environmental issues that seem to have no solution. These social conflicts often have damaging repercussions for the actors and their relationships, the environment, and the economy of the region concerned - communication "deadlock" has a negative influence on many aspects of regional development and results in limited, short-term and non-strategic solutions (cf. Barton, Dlouhá, 2014; Vávra et al., 2014).

\section{Sustainable policies (at regional level)}

As mentioned above, sustainable development is a multidimensional, future-oriented process which requires deliberation between diverse social actors. It is characterized by new modes of environmental governance where these actors are actively involved in a coordinated decision making process, and the effort to integrate different types of expertise is considered to be part of the solution to pressing environmental problems (Hogl et al., 2012: 5). These processes are supposed to be effective because of the emancipation of the actors and their ability to participate - in line with Habermas' concept of deliberative democracy (Dryzek, 1997). This requires considerable social capital, and hence political strategies and their implementation at regional level greatly depend on soft factors such as trust, commitment, network relationships and the specific capabilities of the actors e.g. leadership; the integration of expertise and research in practical activities is of great importance as well (Sol, 2013; Mader, 2013). In the efficient negotiation of highly diverse viewpoints, social learning processes play a role and should be supported or facilitated, as stressed by a number of authors (Wals, 2007, 2009; Dlouhá et al, 2013). Success in the achievement of jointly negotiated goals is then sometimes associated with the 'communities of practice' model (Wenger, 2000).

\section{Social learning}

Social learning is defined in relation to the sum of knowledge in or about a specific situation which is developed by the actors involved in this situation and hence integrates an input from different perspectives and diverse disciplines (cf. Wenger, 2000; Wals, 2007). The transformative effect of social learning on development policies then depends on the knowledge and interests of actors involved in the discussion processes. According to Hall (1993), acceptance of the social learning concept in the policy context is supposed to have three main outcomes: the substantial impact of past policy on recent policy (this policy thus responds less to present social and economic conditions); the key role of experts who specialize in a given field of policy (agents that influence policy changes and so reducing the importance of the role of politicians); and finally it boosts the capacity of the state to act independently of social pressures (lesser influence of outside factors like socioeconomic development, elections, political parties, etc.) (Hall, 1993: 277-278).

\section{Question}

In the first decade of the new century, environmental issues in the Czech Republic gradually lost their popularity - some of the cases which were analysed by the research team (cf. Zahradník et al., 2014) ended in deadlock that has been impossible to resolve over many years. Bottom-up processes in the environmental field driven by NGOs inherited from the past a certain degree of isolation from the rest of society (cf. Sarre, Jehlička, 2007). The sustainable development approach has evolved with difficulty as negotiation processes have not been based on the tradition of deliberation and consultation. This concerns the roles of all actors in social dialogue including scientists: while environmental expertise simply functioned as providing input on the state of the environment and propo- 
sed measures to improve it (which seems to work well in Czech conditions), sustainability expertise requires more active engagement in the policy making process. Consequently, in the sustainability context, scientific knowledge can be generated within and as a result of interaction with other actors.

The following research is focused on the exploration and analysis of communication practices at regional level with the aim of methodically supporting reflection and facilitation in these practices. A review and comparison of Czech case studies collected in an on-line database (Enviwiki 2014) and in the Envigogika special issue (Envigogika, 2015) is presented here. The authors conducted the analysis with respect to the following questions (which were also borne in mind when compiling the cases within the database): (1) Are there any similarities and common characteristics when resolving the regional sustainable issues in cases presented here? (2) What actors played important roles in decision making processes described in them? (3) What were important factors that influenced outcomes of actors' interaction? (4) Was the decision making process top down or bottom up, open, transparent and inclusive, with ongoing communication among all interested parties? (5) What role was usually played by experts and scientists in regional sustainability issues?

\section{Method}

To explore communication processes and describe the role of actors in regional (un)sustainable development issues, a case study approach was used. A case study should "investigate contemporary phenomenon within its real-life context" (Yin, 1994: 16), it may provide insight into the problem under observation and illustrate it (Fry, Ketteridge, Marshall, 1999) or even show its theoretical underpinnings (Davis \& Wilcock, 2003). Case study research might be driven by interest in a single issue, actor, etc., but could also pay attention to multiple cases that might promote generalizations (Dillon \& Reid 2004). Case studies have the great advantages of using a qualitative approach allowing the in depth exploration of particular issues in relation to its contexts (cf. Dlouhá, 2014). In this article, we have observed similar phenomena under different circumstances, and produced several case studies within different genres (scientific, descriptive) which were subsequently analysed.

\section{Research process}

Studies of environmental governance are usually conducted as qualitative case studies (Newig \& Fritsch, 2009b: 3), which is ideal for thorough understanding of particular cases but has its limits in providing more a universal perspective. Despite the controversy between proponents and opponents of qualitative or quantitative methods, both approaches can be successfully combined in a responsible research design. Case studies and a qualitative approach are in general used as tools for the initial mapping of phenomena we want to explore; a quantitative survey is used to further test and validate the hypothesis posed by the initial phase of research (or those emerging from theory) and to correct theoretical statements. A German team of researchers has applied a quantitative case survey method on data gained from elaborate meta-analysis of multiple case studies on environmental governance (47 case studies) with the goal to empirically test the theoretical assumptions about collaborative and participatory decision making processes in environmental issues (Newig \& Fritsch, 2009a: 197).

The authors of this paper did not have at their disposal such a wide range of case studies, however they still attempted to make a step forward in qualitative cross-case analysis (Stake, 2013: 39). The goal was to identify relationships among variables in the con- 
text of the presented case studies and formulate a hypothesis for further research, and also to compare the Czech findings with international experience. A step from caseoriented analysis to variable-oriented cross case analysis (according to Huberman and Miles, 1994: 435 in Babbie, 2013: 390) was made using actor analysis as an interpretational framework.

To describe the situation in the Czech Republic with regards to the main research interest - patterns and means of communication between diverse actors within sustainability oriented processes on regional level - mapping phase was undertaken. Different cases throughout the Czech Republic related to the negotiation processes in environmental or sustainability field were collated and consequently analyzed. In the process of analysis, attention was paid in particular to the roles of actors with special emphasis on the roles of scientists. To this end, the actor analysis method was applied, the purpose of which is to "...identify the relevance of each role player for the process of change and to establish which goals they are pursuing, whether they do it more openly or less transparently 'behind the scenes', with a hidden agenda. Their strengths and weaknesses are noted, and patterns of communication and relationships made transparent." (Zimmermann \& Maennling, 2007: 9). By applying actor analysis (AA), the characteristics of actors in regional development processes and their relationships were explored.

Czech cases were collected in two forms: within the genre of scientific article (accepted in this issue of Envigogika, 2015), and as a briefer, lay description written by practitioners - within a database freely available on the internet (Enviwiki, 2014). From the number of collated cases, nine were considered in the comparison within this research. The obtained "data" were used to explore whether the described Czech decision making processes are open, transparent and inclusive, with ongoing communication among all interested sides. Also the framework conditions (who and in which role initiates, promotes and takes part in decision making process) which are present in strategic regional planning and policy development were analysed. Finally, the experiences received from these national case studies were compared with the situation abroad and reflected in the light of more general and thus more theoretically relevant findings from a wider meta-analysis of environmental management and decision making in regional sustainable issues conducted by other research teams (Newig, 2009a).

\section{Object of study}

This article aims to show the methods or ways of describing, analysing, and identifying principles of consequent action which might transform existing practices, at least in the particular context of the Czech Republic. The main goal of this analysis was to provide a first sketch, explore the situation and help to find an appropriate focus for further research, by developing, among others, a set of variables applicable in broader comparison of multiple case studies. The empirical evidence in the cases collected here varied from qualitative field research using interviews combined with other data sources (Hermová, 2014; Gregorová, 2014), in-depth document analysis (Skalík, 2015) to description based on relevant documents and on personal experience (Kulich, 2014; Mikšíček, 2014). Information from the collected cases was then supplemented by additional consultation or reference to written sources or consultation with key informants when needed. The findings can therefore be considered as initial ones, without the ambition of generalisation to the situation across the Czech Republic

The analysed case studies describe the communication processes through which new solutions emerge, or, on the contrary, that brought about a communication deadlock that was difficult to overcome. Besides paying attention to scientific expertise, the role of NGOs 
has also been highlighted as these organizations have recently developed a significant amount of knowledge in particular spheres of interest (cf. Čada and Ptáčková, 2013).

The majority of the considered cases shares a similar structure (from general description of the issue in question, exposing its regional context, showing the factors influencing the case, including actors, to a conclusion and possible generalization) so that actor analysis tools could be applied. Many of the cases demonstrated some success or failure of environmental or sustainability related deliberative processes under the specific circumstances. As the research question concerned the cross-cutting issue of communication, the collected cases were concerned with a diverse range of sustainability themes. For a brief description of all cases please see attachment.

\section{Research tool}

Actor analysis provided a framework not only for cross-case comparison, but also for initial case study design and definition of variables. This method was not applied here for detailed analysis of each case, undergoing all steps of the process (from problem definition to proposals of practical solution). It rather provided structure for the case study design and consequent comparison of the cases with regard to the (key) actors, their roles, relationships between each other and to the case topic, nature of the decision making process and its results. Selection of the variables for further analysis followed similar categories as in the international case survey (Newig et al. 2013) but only a few variables from this set were selected for the purpose of the small scale research presented here.

Two researchers applied the AA scheme to describe the cases (so that each of the cases was described by both of them); for the meta-analysis they developed:

1. a set of characteristics of communication that included three variables: communication a) takes place/does not take place; b) constructive/mixed nature/conflict; c) face to face/mediated,

2. variables for the role and representation of experts and scientists - three levels: active involvement in decision making/limited involvement as providers of information, consultants/without representation in decision making at all,

3. variables for the outcome in different levels: a) case resolved/not resolved, still in process; b) positive/ambivalent/negative impact on environment; c) positive/ambivalent/negative impact on local community and social capital (whether the conflict was resolved/prevails/has deteriorated or an additional one has arisen).

Information from studies were separately coded and combined, discrepancies resolved through discussions and further consultations with key informants (triangulation process). This allowed the observation of the driving forces behind problematic or successful cases from different regions, as well as from abroad. Generalizations derived from these cases have to be further justified and explored.

\section{Results}

Summarised information was developed in table form (Table 1) for the common interpretation of all cases. To better understand the conditions for success and failure in solving regional sustainability issues, the cases were first sorted according to their outcome. The environmental impact of the decision making process as well as impact on social capital of the local community was coded (negative, ambiguous or positive). The as- 
sessment was done independently by authors for all variables based on information provided by the case study and additional consultations.

The scale of the presented cases varies as well as their focus and empirical approach. The unifying criterion for their collection was that a topic should cover a local or regional sustainable development issue where different interests and social actors have roles and from. Additional criterion was level of completeness of the information provided in the case reports in respect to various social actors' roles. In another words, this collection includes research case studies as well as non-reviewed reports.

More detailed information about the Hostětín Cider House, Tuchomyšl and Šumava 2 cases is available in articles in this Envigogika special issue (Envigogika, 2015). Königsmühle and $\mathrm{Na}$ Plachtě cases are also published in the Envigogika online journal (Mikšíček, 2014; Zahumenská, 2014). Orlík Reservoir and Šumava 1 cases are described in the European Journal of Environmental Sciences (Očásková et al., 2014; Křenová \& Vrba, 2014) and Dotek, Soutok and Jezeři cases can be found along with references to relevant resources in the on-line database (Enviwiki, 2014). Nevertheless, a brief introduction to their focus is provided in the Annex to help orient the reader in the presented topics. 


\begin{tabular}{|c|c|c|c|c|c|}
\hline Case/Author & Focus/Topic & Actors & Framework & Decisive factors & Outcome \\
\hline $\begin{array}{l}\text { Dotek } \\
\text { Kulich, J. (Enviwiki, } \\
\text { 2014) }\end{array}$ & $\begin{array}{l}\text { Rescue and re- } \\
\text { covery of deso- } \\
\text { lated sight }\end{array}$ & $\begin{array}{l}\text { Proponents: } \\
\text { NGOs } \\
\text { local citizens } \\
\text { local municipality } \\
\text { experts and scientists } \\
\text { Opponents: } \\
\text { no strong opponents }\end{array}$ & $\begin{array}{l}\text { Partnership of environ- } \\
\text { mental NGO, local citizens } \\
\text { and municipality }\end{array}$ & $\begin{array}{l}\text { Bottom-up participative process } \\
\text { with active vision holders and en- } \\
\text { gagement of local citizens; social } \\
\text { capital of vision holder; small scale; } \\
\text { nonexistence of strong alternative, } \\
\text { competing vision }\end{array}$ & +++ \\
\hline $\begin{array}{l}\text { Hostětín Cider House } \\
\text { (Labohý, Gailly, Ma- } \\
\text { chů, 2015) }\end{array}$ & $\begin{array}{l}\text { Construction of } \\
\text { cider house } \\
\text { using local orga- } \\
\text { nic products }\end{array}$ & $\begin{array}{l}\text { Proponents: } \\
\text { NGOs } \\
\text { local citizens } \\
\text { local municipality } \\
\text { experts and scientists } \\
\text { Opponents: } \\
\text { no strong opponents }\end{array}$ & $\begin{array}{l}\text { Partnership of environ- } \\
\text { mental NGO, locals and } \\
\text { environmental experts }\end{array}$ & $\begin{array}{l}\text { Bottom-up participative process } \\
\text { with active vision holders and en- } \\
\text { gagement of local citizens; social } \\
\text { capital of vision holder; small scale; } \\
\text { nonexistence of strong alternative, } \\
\text { competing vision }\end{array}$ & +++ \\
\hline $\begin{array}{l}\text { Na Plachtě } \\
\text { (Zahumenská, 201) }\end{array}$ & $\begin{array}{l}\text { Protection of } \\
\text { nature and } \\
\text { community spa- } \\
\text { ce in the city of } \\
\text { Hradec Králové }\end{array}$ & $\begin{array}{l}\text { Proponents: } \\
\text { NGOs } \\
\text { local citizens } \\
\text { experts and scientists } \\
\text { Opponents: } \\
\text { business enterprises } \\
\text { and developers }\end{array}$ & $\begin{array}{l}\text { Partnership of locals and } \\
\text { environmental NGOs and } \\
\text { experts versus (vs.) de- } \\
\text { velopers }\end{array}$ & $\begin{array}{l}\text { Well-being of local citizens - deve- } \\
\text { loper perceived as threat; active } \\
\text { involvement of locals; competing } \\
\text { visions; unclear role of municipality }\end{array}$ & $++/-$ \\
\hline
\end{tabular}




\begin{tabular}{|c|c|c|c|c|c|}
\hline Case/Author & Focus/Topic & Actors & Framework & Decisive factors & Outcome \\
\hline $\begin{array}{l}\text { Königsmühle } \\
\text { (Mikšíček, 2014). }\end{array}$ & $\begin{array}{l}\text { Conservation of } \\
\text { historical foot- } \\
\text { print in the Ore } \\
\text { Mountains that } \\
\text { was on the brink } \\
\text { of being wiped } \\
\text { out }\end{array}$ & $\begin{array}{l}\text { Proponents: } \\
\text { NGOs } \\
\text { experts and scientists } \\
\text { regional municipalities } \\
\text { Opponents: } \\
\text { business enterprises } \\
\text { and developers; some } \\
\text { locals }\end{array}$ & $\begin{array}{l}\text { Partnership of NGO regio- } \\
\text { nal municipalities, experts } \\
\text { and limited agreement of } \\
\text { forestry management } \\
\text { company }\end{array}$ & $\begin{array}{l}\text { Bottom-up activity; enthusiasm and } \\
\text { social capital of vision holder vs. } \\
\text { limits of forestry management } \\
\text { company and rare display of di- } \\
\text { sagreement }\end{array}$ & $++/-$ \\
\hline $\begin{array}{l}\text { Orlík Reservoir } \\
\text { (Očásková et al., } \\
\text { 2014) }\end{array}$ & $\begin{array}{l}\text { Regional resto- } \\
\text { ration develop- } \\
\text { ment project } \\
\text { building on revi- } \\
\text { talisation of } \\
\text { water reservoir. }\end{array}$ & $\begin{array}{l}\text { Proponents: } \\
\text { regional municipalities } \\
\text { experts and scientists } \\
\text { local businesses } \\
\text { Opponents: } \\
\text { business enterprises } \\
\text { and developers; } \\
\text { some locals }\end{array}$ & $\begin{array}{l}\text { Partnership of regional } \\
\text { municipalities, experts } \\
\text { and local businesses vs. } \\
\text { other business and } \\
\text { unsustainable ways of } \\
\text { behaviour of local citizens }\end{array}$ & $\begin{array}{l}\text { Well-being of local citizens; concern } \\
\text { of locals (and experts) about regio- } \\
\text { nal development in context of its } \\
\text { decline due to top-down authority } \\
\text { decision-making process ( } \mathrm{dmp} \text { ) and } \\
\text { unsustainable water management }\end{array}$ & $++/-$ \\
\hline $\begin{array}{l}\text { Soutok } \\
\text { Gregorová, Ž. (En- } \\
\text { viwiki, 2014) }\end{array}$ & $\begin{array}{l}\text { Controversy } \\
\text { concerning pro- } \\
\text { posal of a new } \\
\text { landscape pro- } \\
\text { tected area }\end{array}$ & $\begin{array}{l}\text { Proponents: } \\
\text { state authorities } \\
\text { experts and scientists } \\
\text { Opponents: } \\
\text { regional municipali- } \\
\text { ties; } \\
\text { business enterprises } \\
\text { and developers; } \\
\text { local citizens }\end{array}$ & $\begin{array}{l}\text { Union of locals and fo- } \\
\text { restry management com- } \\
\text { pany vs. State, environ- } \\
\text { mental NGOs and experts }\end{array}$ & $\begin{array}{l}\text { Well-being of local citizens - high } \\
\text { environmental conservation stan- } \\
\text { dards perceived as threat; } \\
\text { initially top-down dmp; competing } \\
\text { visions }\end{array}$ & $--/+$ \\
\hline
\end{tabular}




\begin{tabular}{|c|c|c|c|c|c|}
\hline Case/Author & Focus/Topic & Actors & Framework & Decisive factors & Outcome \\
\hline $\begin{array}{l}\text { Jezeří } \\
\text { Marek, J., Barton, A. } \\
\text { (Enviwiki, 2014); } \\
\text { (Dlouhá, Barton, } \\
\text { 2014) }\end{array}$ & $\begin{array}{l}\text { Conservation } \\
\text { and struggle for } \\
\text { survival of Jezeří } \\
\text { Chateau }\end{array}$ & $\begin{array}{l}\text { Proponents: } \\
\text { NGOs } \\
\text { local citizens } \\
\text { local municipality } \\
\text { experts and scientists } \\
\text { Opponents: } \\
\text { business enterprises } \\
\text { and developers; }\end{array}$ & $\begin{array}{l}\text { Local activists, NGOs and } \\
\text { local municipality vs. } \\
\text { mining company }\end{array}$ & $\begin{array}{l}\text { Top-down decision making process; } \\
\text { authoritative power vs. active in- } \\
\text { volvement of locals; competing } \\
\text { visions }\end{array}$ & $--/+$ \\
\hline $\begin{array}{l}\text { Tuchomyšl } \\
\text { (Hermová, } \\
\text { 2015) }\end{array}$ & $\begin{array}{l}\text { Qualitative re- } \\
\text { search among } \\
\text { inhabitants of } \\
\text { obliterated villa- } \\
\text { ge }\end{array}$ & $\begin{array}{l}\text { Proponents: } \\
\text { local citizens } \\
\text { Opponents: } \\
\text { business enterprises } \\
\text { and developers; } \\
\text { state authority }\end{array}$ & $\begin{array}{l}\text { State and mining compa- } \\
\text { ny obliterated villages } \\
\text { and towns due to mining }\end{array}$ & $\begin{array}{l}\text { Top-down decision making process; } \\
\text { authoritative power vs. desire to } \\
\text { maintain social capital of locals; } \\
\text { competing visions }\end{array}$ & $--/+$ \\
\hline \multirow[t]{2}{*}{$\begin{array}{l}\text { Šumava } 1 \\
\text { (Křenová, Vrba, 2014) }\end{array}$} & $\begin{array}{l}\text { Controversies } \\
\text { related to Šu- } \\
\text { mava National } \\
\text { Park from envi- } \\
\text { ronmental scien- } \\
\text { tists' perspecti- } \\
\text { ve }\end{array}$ & $\begin{array}{l}\text { Proponents: } \\
\text { experts and scientists } \\
\text { Opponents: } \\
\text { regional municipali- } \\
\text { ties; } \\
\text { business enterprises } \\
\text { and developers; } \\
\text { local citizens }\end{array}$ & $\begin{array}{l}\text { Local citizens and munici- } \\
\text { palities and forestry ma- } \\
\text { nagement company vs. } \\
\text { environmental NGOs and } \\
\text { experts }\end{array}$ & $\begin{array}{l}\text { Well-being of local citizens - high } \\
\text { environmental conservation stan- } \\
\text { dards perceived as threat; } \\
\text { Initially top-down dmp; } \\
\text { inconsistent role of state; compe- } \\
\text { ting visions }\end{array}$ & --- \\
\hline & $\begin{array}{l}\text { Content analysis } \\
\text { of debate about }\end{array}$ & Proponents: & $\begin{array}{l}\text { Local citizens and munici- } \\
\text { palities and forestry ma- }\end{array}$ & $\begin{array}{l}\text { Well-being of local citizens - high } \\
\text { environmental conservation stan- }\end{array}$ & --- \\
\hline
\end{tabular}




\begin{tabular}{|l|l|l|l|l|}
\hline Case/Author & Focus/Topic & Actors & Framework & Decisive factors \\
\hline Šumava 2 & $\begin{array}{l}\text { Śumava National } \\
\text { Park in the } \\
\text { Czech chambre } \\
\text { of Deputies }\end{array}$ & $\begin{array}{l}\text { Opperts and scientists } \\
\text { Opgional municipali- } \\
\text { ties; } \\
\text { business enterprises } \\
\text { (Skalík, 2015) } \\
\text { local citizens }\end{array}$ & $\begin{array}{l}\text { nagement company vs. } \\
\text { environmental NGOs and } \\
\text { experts }\end{array}$ & $\begin{array}{l}\text { dards perceived as threat } \\
\text { Initially top-down dmp; } \\
\text { inconsistent role of state; compe- } \\
\text { ting visions }\end{array}$ \\
\hline
\end{tabular}

Table 1. List of analysed Czech cases, their characteristics and main findings of the analysis. The "Framework" describes the network of actors and their position towards the issue. "Decisive factors" represents authors' interpretation of crucial factors which influence the outcomes of the cases (e.g. bottom-up processes defined within decision making process which are driven by a small non-state actor, a low-level governmental body or local citizens). "Outcome" is assessed on a 4 point scale from negative $(---)$, semi negative $(--/+)$, semi-positive (++/-) to positive $(+++)$ outcome in terms of environment and social capital (order of symbols represents only the prevailing assessment). 


\section{Interpretation framework}

According to our categorisation, only three of the considered cases represent actually resolved issues, yet in the decision making processes we can observe either positive or negative impacts on the local situation.

Among the successful cases we include the Hostětín cider house project and Dotek (recovery of a desolated presbytery). Königsmühle cultural heritage protection, Revitalisation of the Orlík Reservoir and protection of Na Plachtě nature monument represent ambiguous cases. Conflict about the landscape protected area CHKO Soutok represents a failure in terms of introducing high environmental protection standards, but there is a biosphere reservation in place which is well evaluated by UNESCO. Studies on Šumava National Park, displacement of Tuchomyšl village and The Battle for Jezeří Chateau describe failures to reach agreement on a sustainable vision of regional development.

\section{Actors and their roles}

We can identify similarities in both successful and unsuccessful cases. Our interest was focused on the role and characteristics of key actors and primarily on the role of experts and scientists. In all cases we observed these experts as external elements. Even in the successful cases, when scientists act together with NGOs as proponents of a vision of sustainable development, the experts were not local to the region.

Scientists predominantly act on behalf of proponents of sustainable development, but their role may vary and their importance in decision making process increases when their expertise is required by one of the involved actors. The role of experts is then determined by those who set their task (cf. Dlouhá, Barton, 2014).

When environmental conservation is at stake, environmentally oriented scientists take the role of proponents of high ecological standards (as do NGOs). For example in the Šumava National Park cases scientists' studies stressed the unique value of the largest wild area in cultural landscape of Central Europe and the importance of its conservation. Scientists then played an active role in discussions on forestry management strategy. Various statements and open letters addressed to politicians were signed by numerous Czech and international scientific institutions and societies (e.g. Environmental Committee, Global Change Research Centre and Biology Centre of the Czech Academy of Sciences, Faculties of Nature Sciences from four Czech universities, WWF International, IUCN Wilderness Specialist Group, etc.). An instructive documentary film by Silva Gabreta was created in support of the non-intervention approach in National Park. Similarly, in the Soutok case scientists emphasise the value of the natural river confluence and promote its conservation by establishing a new protected area. Environmentally oriented NGOs (Friends of the Earth, Greenpeace, Green Circle, etc.) naturally take part in these cases on behalf of nature conservation and often collaborate with scientists or develop their own expertise (cf. Čada, Ptáčková, 2013). A situation in which locals prioritise economic utilization of natural resources and are supported by politicians seeking to profit from the controversy can lead to communication failure and a struggle between two opposing camps of proponents and opponents of conservation with negative consequences for local sustainable development and social capital.

When we take a closer look at actors who act as the main proponents and opponents of environmentally oriented sustainable development in our cases, we identify some of them taking both roles. We can identify NGOs as vision holders (in the cases of Hostětín, Dotek, Königsmühle, and Na Plachtě), state authorities (Šumava, Soutok), local municipalities and scientists (Orlík) or other groups of local citizens (Jezeří). Among main oppo- 
nents we find local municipalities and citizens (Šumava, Soutok), state authorities (Tuchomyšl, and an unclear position in Jezeři and Šumava), business enterprises and developers (Na Plachtě, Soutok, Šumava, Jezeří).

\section{Factors of success or failure}

An important decisive factor in our case studies appeared to be the active involvement and cooperation with local actors (citizens, municipalities. etc.) on the vision development. When locals understand and share the vision, at least to a certain extent, they take the role of proponents and co-creators or at least do not actively oppose it. On the other hand when they perceive plans to enforce high environmental protection standards as a threat to their wellbeing, they tend to oppose the environmental development plan.

Such a participative process of vision development took place in both successful cases. The vision holders responsible for innovative ideas were NGOs with considerable social capital (including relationships with experts). The NGOs were able to openly share their point of view with local citizens and municipalities and decision making processes were transparent and inclusive, included face to face communication, and resulted in the active involvement of local citizens and municipalities in the realization of proposed projects.

The decision making processes were bottom-up initiatives of NGOs and the scale of their communication outreach was not too broad (NGOs and their active social networks, local municipalities and citizens). Engagement at state level was not necessary for the creative planning process. Besides external vision holders, there were also external financial resources which enabled realization of both projects (the Luxembourg Ministries of the Environment and Foreign Affairs, and credit confirmed from the Luxembourg ethical bank, Alterfinanz, in Hostětín and EU funds via the Czech Ministry of the Environment in Dotek in Horní Maršov).

The realization of sustainable projects led to economic, environmental, social and cultural profit in both successful cases. In Hostětín the cider house project is only one of many activities based on a network of locals, NGOs and experts. There are many examples of its beneficial impact. The new enterprise uses traditional knowledge and provides profit and employment. But the very first activity that took place in Hostětín was the building of a reed bed treatment plant that enabled the removal of a construction ban and started the whole revitalisation of a village. In Horní Maršov (Dotek case) the desolated baroque presbytery was reconstructed and a unique environmental centre was established where to date numerous educational programs have taken place.

The leading motive of regional development vision was usually not environmental conservation. The reasoning was dominated by other local needs (e.g. prosperity of the local economy or support for local tourism). The absence of a strong alternative, competing vision was also one of the crucial features of success. This fact is even more evident when we focus on less successful cases. The factors of failure or potential barriers to sucess are summarized as follows:

Conflict arose when no widely accepted vision of development was formulated and the actors were forced to choose between two controversial situations. Typically there was a strong economic interest (represented by a developer or other strong commercial entrepreneur) in conflict with environmental protection. Those promoting a vision of sustainability failed to gain significant support for their vision among locals and regional representatives such as municipalities. The locals perceived environmental protection as a threat to their well-being and prosperity of the region, which was used as a strong argument by 
opponents of environmental conservation in the political debate (Šumava, Soutok). In these cases, the decision making processes had a primarily top-down design with limited place for the participation of local citizens, even at the initial stage. State authorities and high ranking politicians were inconsistent in their role and tended to profit politically from the conflict (Šumava and Soutok). A combination of the factors resulted in the "deadlock" of communication and loss of regional social capital. The cases of Šumava represent a clear example of loss of trust among actors, manipulative use of expertise and conflicting modes of communication with even physical violence.

Based on these findings, hypothesis about social capital and its two-directional relationship with the success of decision-making processes can be posed. For example Rataj (2014) in his research study on social capital in Šumava refers to the social capital in place, but mainly as a network of local mayors and municipalities. In respect to the National Park particularly problematic is the loss of trust among locals, who perceive the unstable position of the park caused by political turbulences and changes in management of the park as a threat. As a result there is low involvement of the municipalities in decision making concerning the National Park, and as a result conflict situations appear. Nevertheless, locals still perceive a positive aspect of National Park as it attracts tourists and hence has an impact on local economy. The study does not explicitly explore the role of scientists, but focuses on the conflicts between locals and environmental NGOs. Other examples may not be as extreme, but loss of trust and failure of negotiation is also apparent in the Soutok and Jezeří cases.

Essentially we can observe two modes of vision development, decision making process and communication among actors: primarily top-down and non-participative - often resulting in conflict; versus a participative bottom-up approach with face to face communication. The latter we find more promising yet not necessary sufficient for guaranteeing a successful result (other factors may affect the outcome as well: strong economic interests competing with the sustainable vision, inconsistent politicians and locals threatened by the prospect of the loss of well-being). Active attempts to build constructive communication frameworks (possibly with a role of independent observer and facilitator) are also crucially important: in those cases where attempts to build such a framework failed, conflicts and mistrust emerged between different social groups with a damaging effect on relationships among the actors and a poor prospect of finding a shared solution in the foreseeable future (Šumava; Tuchomyšl (eviction); Jezeří; Soutok).

\section{Discussion}

When environmental conservation is a dominant topic, we predominantly perceive two basic scenarios - a finding which corresponds with international experience. The first scenario is a controversy between a strong economic interest (e.g. industrial polluter or developer) and the protection of local environment. Once local citizens perceive their personal health and well-being in danger they act in partnership with environmental NGOs and scientists to oppose the threat (as in Na Plachtě and Jezeří cases or Colstrip case in USA in Newig, Fritsch 2009a).

The second scenario, already mentioned, is the reverse situation when high ecological standards promoted by NGOs, state or environmentally oriented scientists (but not locals) are perceived by local citizens as threat to their well-being, regardless of whether it is in Germany, USA or in Czech Republic (Šumava, Soutok). The hypothesis tested in international meta-analysis is then valid: Citizens living in close spatial proximity to a natural 
resource tend to favour its economic exploitation, whereas those living farther away tend to favour its conservation (Newig \& Fritsch, 2009a: 206).

Other cases (cf. Enviwiki, 2014) describe non-sustainable practices, the negative effects of which have been proven for decades yet with little effect on policy-making (the influence of powerful lobbying of economic interests). In these cases, scientists might be employed to defend unsustainable practices which sometimes leads to ethical misconduct (providing questionable data to support unsustainable policies, cf. Dlouhá, Barton, 2014). Adoption of a more complex sustainability vision could help under these circumstances, as then a wider range of development opportunities can be offered to local inhabitants and consequently an ideological interpretation of the issue can be abandoned (a less blackand-white view is possible). On the other hand, the involvement of scientists might reinforce the momentum behind regional development as they are, for example, able to identify and convey the new opportunities documented (e.g. where an aspect of sustainable development is needed in the region for the promotion of tourism and development is then driven by interest in changing business-as-usual). This evidence can be a basis for further thoughts about the role of science in policymaking which in an environmental framework is supposed to be substantially changed towards participatory involvement (cf. Bäckstrand, 2003; Hanssen et al., 2009).

The results of our comparison concur with international meta-analysis in terms of the evidence of positive impacts of face-to face communication and in fact, that collaborative agreements often represent a compromise between competing interests rather than the collective search for eco optimal solutions (Newig \& Fritsch 2009a: 205). For such an agreement it is crucial to carefully nurture transparent relationships based on trust among the actors from the outset. Where development is spontaneous, controversy among the actors often persists or is even exacerbated ${ }^{1}$. Where, on the other hand, a framework for communication has been developed, and discussions facilitated, the outcome is more successful in terms of setting a strategy for regional SD and consequent actor involvement ${ }^{2}$. This finding is in accordance with most of the theoretical assumptions on participation in the literature but empirical evidence of various studies is insufficient, providing only sporadic evidence which is ambivalent in its conclusions (Newig in Hogl et. al. 2012: 58).

In general, to agree upon workable scenarios and implement practical solutions at regional level, the development of an appropriate communications framework is needed, and possibly also facilitation of a dialogue between the actors, as well as continuous reflection on the process itself - this is one of the experiences highlighted in the successful cases. As part of communication between actors from different backgrounds, a social learning process is likely to have the potential to transform viewpoints and approaches of those involved so that final agreement is made possible. A question remains over who can

\footnotetext{
${ }^{1}$ As visible in cases Šumava, Jezeři, Soutok. Šumava National park and controversy on the new Soutok protected area represent such cases. The Šumava case in particular, in both studies, shows how the initial controversy between forestry management and nature conservation is used by other actors, specifically politicians, to gain political profit, utilising the conflict rather than seeking a transparent position and setting conditions for open discussion. A history of vicarious and conflictive communication between two opposite sides has deepened the controversy and makes the negotiation more difficult than in the initial stage of problem definition.

${ }^{2}$ For example in the Orlík Reservoir, Dotek, Hostětín cases. The Orlík Reservoir revitalisation project also had to face opponents, but a series of public meetings and negotiation succeeded in creating a network of cooperating actors with shared vision of local prosperity based on environmental management.
} 
formulate a framework for communication and how the participation of actors can be promoted. Experience shows that scientists and experts on communication might also play a role here. This practise is far more common in solving environmental issues abroad as revealed in many cases from the international meta-analysis (Newig \&Fritsch 2009a: 204), the Yukon wolf management team being exemplary in this respect (Todd, 2002).

Our research was exploratory - we have analysed a collection of cases compiled in various forms; some of them were described in-depth, the others were included in more lay form in the database. The actor analysis method was used to generalize experience from the cases and provided initial data for the first insight in this issue. This method has been widely used for facilitation, testing hypotheses, field research, etc. (cf. Burandt, 2015); for more comprehensive reflection it might be complemented by more sophisticated methodologies (network analyses, scenario analyses). In the presented research the method has revealed relationships that should be nurtured in practice and allowed us to make a few generalisations that will be interesting to further explore theoretically.

\section{Conclusion}

The cases briefly described in this article demonstrate the context for and results of developing and implementing sustainability related strategies at regional level. The successful cases were based on a sustainability vision and included the dimension of innovation - but these were often brought from outside the region, as innovative practices are usually "not visible" to regional policy makers. On the other hand, where innovation was required for a particular reason (deteriorating environmental quality with a negative impact on tourism, regional economic problems) - then an opportunity to negotiate a SD solution emerged and was sometimes utilized by enlightened actors. Deadlock appeared where no innovative and widely acceptable approach was developed and actors had simply to choose between two controversial sides of the status-quo. These situations brought about considerable decline in the social capital of the region with negative effects on other fields - especially economic (although economic policies also contributed to the crises).

Involvement of local actors (inhabitants, municipalities) and convincing them of the benefits of a development vision appeared to be a fundamental condition of success.

The establishment of a communication framework for the involvement of actors (described in some of the cases) promoted processes of deliberation and supported the emergence of innovative solutions. The role of expertise in these innovative practices was crucial; in our cases, experts were often those who introduced new visions and were then able to implement them into practice. In all of these cases, negotiation was required to ensure that the process was driven by regional policy requirements. In some of the analysed cases, scientists have also played the role of facilitators, which shows that innovative SD practices are still based on strong leadership and the experts have considerable authority in social dialogue.

Based on this experience, broader discussions about top-down versus bottom-up processes in which scientists are involved could be held, with the preliminary conclusion that the role of science in sustainable regional development is also becoming more and more decentralised, and science is entering into multiple interactions with other social actors (in the process of which it is also changing). This generated the following question for further research: If these bottom-up processes are inevitable for democratic decisionmaking, then how would scientists involve themselves in such a way that their discourse, potential contribution and hence their specific role could be respected in the given issue 
(as well as of those of other actors)? In our exploratory research, other questions also appeared: Under what circumstances is the potential of science and expertise most efficiently used within regional SD processes? What is the role of strategic deliberation and how should this be conducted? Who will play the role of an unbiased facilitator and who will communicate the vision which is necessary for the transformation of current practices?

In this research, several cases in the Czech policy environment on local to regional level were described and analysed. This represents a first attempt to undertake comparative meta-analysis of environmental cases from the actor point of view in CR. The research shows how important it is to investigate social aspects of regional development issues this kind of reflection helps to obtain some insight into ongoing processes of policy formulation and decision-making with a prospect of wider research allowing more solid generalisations so that experiences could be even transferred to other contexts. From a practical point of view it reveals the potential of the actor analysis method to map important relationships between key and other stakeholders in a particular case and to predict (and influence) the impact of these relations on the resulting decisions and strategies.

\section{Acknowledgement}

The article was supported the Technology Agency of the Czech Republic, project TD020120 (Analysis and support for participatory decision-making processes aimed at regional sustainable development strategies through the use of actor analysis methodology).

\section{References}

- Babbie, E. 2013. The practice of social research. Belmont: Wadsworth Cengage Learning.

- Bäckstrand, K. (2003). Civic science for sustainability: reframing the role of experts, policy-makers and citizens in environmental governance. Global Environmental Politics, 3(4), 24-41.

- Baranek, E. and B. Günther. 2005. Erfolgsfaktoren von Partizipation in Naturschutzgroßprojekten - Das Beispiel: Moderationsverfahren im Gewässerrandstreifenprojekt Spreewald. In Partizipation, Öffentlichkeitsbeteiligung, Nachhaltigkeit. Perspektiven der Politischen Ökonomie, eds. P.H. Feindt and J. Newig. Marburg: Metropolis-Verlag: 299-319.

- Barton, A., \& Dlouhá, J. (eds.) (2014). Exploring regional sustainable development issues. Using the case study approach in higher education. Grosvenor House Publishing LTD., UK

- Burandt, S. 2014. Integration of Actor Analysis in Case Studies for (regional) Sustainable Development. Under review

- Čada, K., Ptáčková, K. 2013. Possibilities and limits of collaboration between science and NGOs in the Czech Republic, Journal of Cleaner Production, Volume 49, June 2013, pp. 25-34 
- Davis, C. \& Wilcock, E. 2003. Teaching Materials Using Case Studies, The UK Centre for Materials Education. [online] [cit 2014-01-30]

http://www.materials.ac.uk/guides/casestudies.asp

- Dillon, J., \& Reid, A. 2004. Issues in case-study methodology in investigating environmental and sustainability issues in higher education: towards a problem-based approach? Environmental Education Research, 10(1), 23-37.

- Dlouhá J. (2014). Sustainable development case studies and their use as a teaching method in regionally focused higher education programs. In: Barton, A., Dlouhá, J., eds. (2014). Exploring regional sustainable development issues. Using the case study approach in higher education. Grosvenor House Publishing LTD., UK

- Dlouhá, J., \& Dlouhý, J. 2014. Higher education for sustainability - a change of education genre? (Vzdělávání pro udržitelnost na vysokých školách - jde o změnu vzdělávacího žánru?) Envigogika, 9(1). Available from http://envigogika.cuni.cz/index.php/Envigogika/article/view/440 DOI: http://dx.doi.org/10.14712/18023061.440

- Dlouhá, J., Barton, A. 2014. Students' exploration of a Brown Coal Mining case study in higher education. In Barton, A. \& Dlouhá, J. (eds.) Exploring regional sustainable development issues. Using the case study approach in higher education

- Dlouhá, J., Barton, A., Janoušková, S., \& Dlouhý, J. 2013. Social learning indicators in sustainability-oriented regional learning networks, Journal of Cleaner Production, Volume 49, June 2013, pp. 64-73.

- Dryzek, J. 1997. The Politics of Earth, Environmental Discourses. New York: Oxford University Press.

- Envigogika 2015. Vol 10, No 1

- Enviwiki 2014. "Případy kauz udržitelného rozvoje" (Case studies of sustainable development). Avaliable from

http://www.enviwiki.cz/wiki/Kategorie:P\%C5\%99\%C3\%ADpady_kauz_udr\%C5\%B Eiteln\%C3\%A9ho rozvoje

- Fry H., Ketteridge S. and Marshall S. 1999. A Handbook for Teaching and Learning in Higher Education, Kogan Page, Glasgow, pp 408.

- Funtowicz, S.O., Ravetz, J. R. 2002. Post-Normal Science - Environmental Policy under Conditions of Complexity, [online] [cit 2006-04-25], from < http://www.nusap.net >

- Hall, P. A. 1993. Policy paradigms, social learning, and the state: the case of economic policymaking in Britain. Comparative politics, 25(3), 275-296.

- Hanssen, L., Rouwette, E., \& Van Katwijk, M. M. (2009). The role of ecological science in environmental policy making: from a pacification toward a facilitation strategy. Ecology and Society, 14(1), 43.

- Hermová, I. 2014. Druhý život Tuchomyšle: Lokální identita přesídlenců z odtěžené obce. (The Second Life of Tuchomyšl: Local Identity of Displaced People From a Strip-Mined Village) Envigogika, 9(2). DOI: http://dx.doi.org/10.14712/18023061.435 
- Hessels, L. K., \& Van Lente, H. 2008. Re-thinking new knowledge production: A literature review and a research agenda, Research policy, 37(4), 740-760.

- Hogl, K., Kvarda, E., Nordbeck, R., Pregernig, M. 2012. Environmental Governance: The Challenge of Legitimacy and Effectiveness. Cheltenham, UK ; Northampton, MA, USA: Edward Elgar Pub.

- Kružíková, E. 2005. EU Accession and Legal Change: Accomplishments and Challenges in the Czech Case. In Carmin, J., VanDeveer, S. D. (2005). EU enlargement and the environment: institutional change and environmental policy in Central and Eastern Europe. New York, Routledge. ISBN 0-415-35186-3. pp. 99-113

- Křenová, Z., Vrba, J. 2014. Just how many obstacles are there to creating a National Park? A case study from the Šumava National Park. European Journal of Environmental Sciences, 4(1). Retrieved from http://ejes.cz/index.php/ejes/article/view/150

- Labohý, J., Gaillyová, Y., \& Machů, R. 2015. A sustainability assessment of the Hostětín cider house project. Envigogika, 10(1). DOI:

http://dx.doi.org/10.14712/18023061.449

- Mader, C. 2013. Sustainability process assessment on transformative potentials: the Graz Model for Integrative Development, Journal of cleaner production, 49, 54-63.

- Mebratu, D. 1998. Sustainability and sustainable development: historical and conceptual review. Environmental impact assessment review, 18(6), 493-520. Dostupné z http://www.sciencedirect.com/science/article/pii/S0195925598000195

- Mikšíček, P. 2014. Objev údajně vyhubeného sídelního druhu uskutečněn na Königsmühle $v$ Krušných horách. (Discovery of a supposed extinct settlement species made at Königsmühle in the Ore Mountains) Envigogika, 9(1). DOI: http://dx.doi.org/10.14712/18023061.441

- Newig, J., Fritsch, O. 2009a. Environmental governance: participatory, multi-level - and effective? Environmental Policy and Governance, 19(3), 197-214. doi:10.1002/eet.509

- Newig, J., Fritsch, O. 2009b. The case survey method and applications in political science. APSA 2009 Toronto Meeting Paper. [online] [2014-10-30] http://papers.ssrn.com/sol3/papers.cfm?abstract id $=1451643$

- Newig, J., Adzersen, A., Challies, E., Fritsch, O. \& Jager, N. (2013). Comparative analysis of public environmental decision-making processes - a variable-based analytical scheme. Institute for Environmental and Sustainability Communication. Research Group Governance, Participation and Sustainability. Leuphana University Luneburgh. Retrieved from http://ssrn.com/abstract $=2245518$

- Očásková, I., Vrba, J., Průša, L. 2014. Revitalisation of Orlík reservoir - case study of a regional restoration project. European Journal of Environmental Sciences, 4(1). Retrieved from http://ejes.cz/index.php/ejes/article/view/152 
- Rataj, S. (2014). Local Actors and Social Networks in The Šumava National park. Master thesis. Faculty of Science, Charles University in Prague. Retrieved from https://is.cuni.cz/webapps/zzp/detail/119946/

- Sarre, P. \& Jehlička, P. 2007. Environmental movements in space-time: the Czech and Slovak republics from Stalinism to post-socialism. Transactions of the Institute of British Geographers 32, 346-362 (2007).

- Skalík, J. 2015. Debate about the Šumava National Park in the Czech Chamber of Deputies. Envigogika, 10(1). DOI: http://dx.doi.org/10.14712/18023061.429

- Sol, J., Beers, P. J., \& Wals, A. E. J. 2013. Social learning in regional innovation networks: Trust, commitment and reframing as emergent properties of interaction, Journal of Cleaner Production, Volume 49, June 2013, pp. 35-43

- Stake, R., E. 2006. Multiple Case Study Analysis. New York: The Guilford Press.

- Sullivan, T., J., 1983. The Difficulties of Mandatory Negotiation (The Colstrip Power Plant Case). In Resolving Environmental Regulatory Disputes, eds. L. Susskind, L. Bacow and M. Wheeler. Cambridge: Schenkman Publishing Company: 56-85.

- Todd, S. 2002. Building consensus on divisive issues: a case study of the Yukon wolf management team. Environmental Impact Assessment Review 22: 655-84.

- Vaněk, M. 1996. It was not possible to breath here: ecology in the Czech Lands since 1968 till 1989 (Nedalo se tady dýchat: ekologie v českých zemích v letech 1968 až 1989), Praha, MAXDORF.

- Vávra, J., Lapka, M., \& Cudlínová, E. (eds.) (2014). Curent Challenges of Central Europe. Praha: UK, Filosofická fakulta. ISBN 978-80-7308-551-3

- Vavroušek, J., Moldan, B. (eds.). 1989. State and development of the environment in the Czech Republic. (Stav a vývoj životního prostředí v Československu) Ekological Section of the Czechoslovak Biological Society of the Academy of Sciences, Praha, $146 \mathrm{p}$.

- Wals, A. E. 2009. Review of Contexts and Structures for Education for Sustainable Development, UNESCO, Paris, Section for DESD Coordination.

- Wals, A. E. (ed.) 2007. Social learning towards a sustainable world, Wageningen Academic Publishers.

- Wenger, E. 2000. Communities of practice and social learning systems, Organization, $7(2), 225$.

- Yin, R. K. 2014. Case study research: Design and methods, Sage, London.

- Zahradník, M., Dlouhá, J., Burandt, S. Actor analysis as a tool for exploring the decision-making processes in environmental governance. In Barton, A. \& Dlouhá, J. (eds.) Exploring regional sustainable development issues. Using the case study approach in higher education.

- Zahumenská, V. 2014. Hradec Králové - ochrana prírodní památky Na Plachtě před zástavbou. Př́padová studie k významu účasti veřejnosti při ochraně životního prostředí. (Protecting the 'Na Plachtě' natural monument from development. A case 
study on the importance of public participation in environmental protection). Envigogika, 9(2). DOI: http://dx.doi.org/10.14712/18023061.451

- Zimmermann, A. \& Maennling, C. (2007). Mainstreaming participation. Multistakeholder management: Tools for Stakeholder Analysis. Federal Ministry for Economic Cooperation and Development. Deutsche Gesellschaft fur Technische Zusammenarbeit (GTZ) GmbH, Eschborn. Retrieved from http://www.fsnnetwork.org/sites/default/files/en-svmp-instrumenteakteuersanalyse.pdf

\section{Annex}

Dotek case describes rescue and recovery of desolated sight. This case presents successful connection of the recovery of a listed building with green technologies and architecture. The building has to be used for education, social events and sustainable tourism. The case report is written by one of the initiators of the project, based on his knowledge, experience and expert architectonical study.

Hostětín Cider House is a sustainability-oriented local economy project. Its origin, development and operation, funding, and relationships with involved actors are described in the study. Sustainability characteristics are outlined with regards to the technology used, including energy resources, the apples used in the production process (which represent local cultural heritage), products and waste. Effects on the local economy are measured using the local multiplier effect indicator. Case study was conducted by proponents of the project.

Na Plachtě is area located at the south-eastern edge of Hradec Králové where over the past 20 years conflicts of interests between environmentalists and local developers have arisen concerning the development and commercial use of the site. The study describes the decision-making process with public involvement and participation in the environmental issue at stake, which have an impact on the work of regional representatives, changing the landscape plan and declaration of the Na Plachtě site as a "natural monument". Case study is based on personal knowledge and documents review of the author, who is lawyer and also expert of involved NGO.

Königsmühle cultural heritage protection is a case of negotiation of association for preservation of landscape footprints from bygone generations of inhabitants in Ore Mountain region with land owners and their interests. In this case the footprint is represented by remains village Königsmühle, which was on the brink of being wiped out. Case is written by promoter of conservation of the site.

Orlík Reservoir revitalisation is a case study of ongoing regional restoration project aiming on sustainable regional development through water management. The case describes the eutrophication of Orlík reservoir, which resulted in water blooms, which in association with socio-economic changes caused a decline in tourism in this region and serious difficulties for local people. The restoration project established a framework of scientists, local people and municipalities with aim to resolve the environmental problem (cleaning the water reservoir) as a starting point for broader socio economic revitalisation of the area. Case study is written by involved experts from university. 
Soutok - regional conflict between proponents and opponents of setting up a new landscape protected area in rivers' Morava and Dyje confluence in south Moravia. The area provides natural habitats many rare animals, plants and fungi. All together hundreds of species of endangered organisms that live there at a single locality in the country or have their center of gravity height there. But there are competing intersts of local businesses and forestry. Economical usage mainly by forestry management company and fear of local municipalities from too strict rules of proposed conservation by official landscape park raised a controversy between proponents and opponents of the park. The study is based several resources, mainly on research master thesis by Gregorová (2014).

Jezeři case describes "a battle for survival" of historical chateau on the border of brown coal mine. Interest of local activists, NGOs and local municipality who seek for conservation and reconstruction of the historical site is in conflict with effort of coal mining company to proceed with mining. Case study is combining various resources, including expert studies, reports, public media articles, documentary film and students' work in exploration of the situation during two summer schools with limited research and interviews key actors.

Tuchomyšl represents a case of resettled village to newly built prefabricated housing estates due to brown coal mining in North Bohemia. Based on an anthropological analysis of biographic interviews with the displaced people of Tuchomyšl, this case study demonstrates how the former Tuchomyšlers identify with the physical space of the village, today nonexistent, and how they reflect on the forced eviction.

Šumava 1 and Šumava 2 cases relate to the same topic, using different perspective and method. Křenová and Vrba report the recent history of nature conservation in the Bohemian Forest, and status of Šumava National Park, which has been questioned, compromised or debated since its foundation and never received clear political support. Discussions about future of the National Park were held mainly on the appropriate management of the forests, i.e. "non-intervention" management versus "necessary" bark-beetle control. Their study analyses the problem from nature scientists' point of view. Skalík, on the other hand, provides in his study deep insight into formal political debate of legislation and parliamentary plenary debates applying corpus pattern document analysis. The study concludes that politicians use the situation in Šumava to support their political strategies. 